International Journal of

Agriculture

(IJA)

\title{
EFFECTS OF PHOSPHORUS AVAILABILITY ON NODULATION AND NITROGEN UPTAKE BY THREE LEGUME CROPS IN TWO GHANAIAN SOILS
}

Alex Boateng and Prof. Emmanuel Owusu-Bennoah

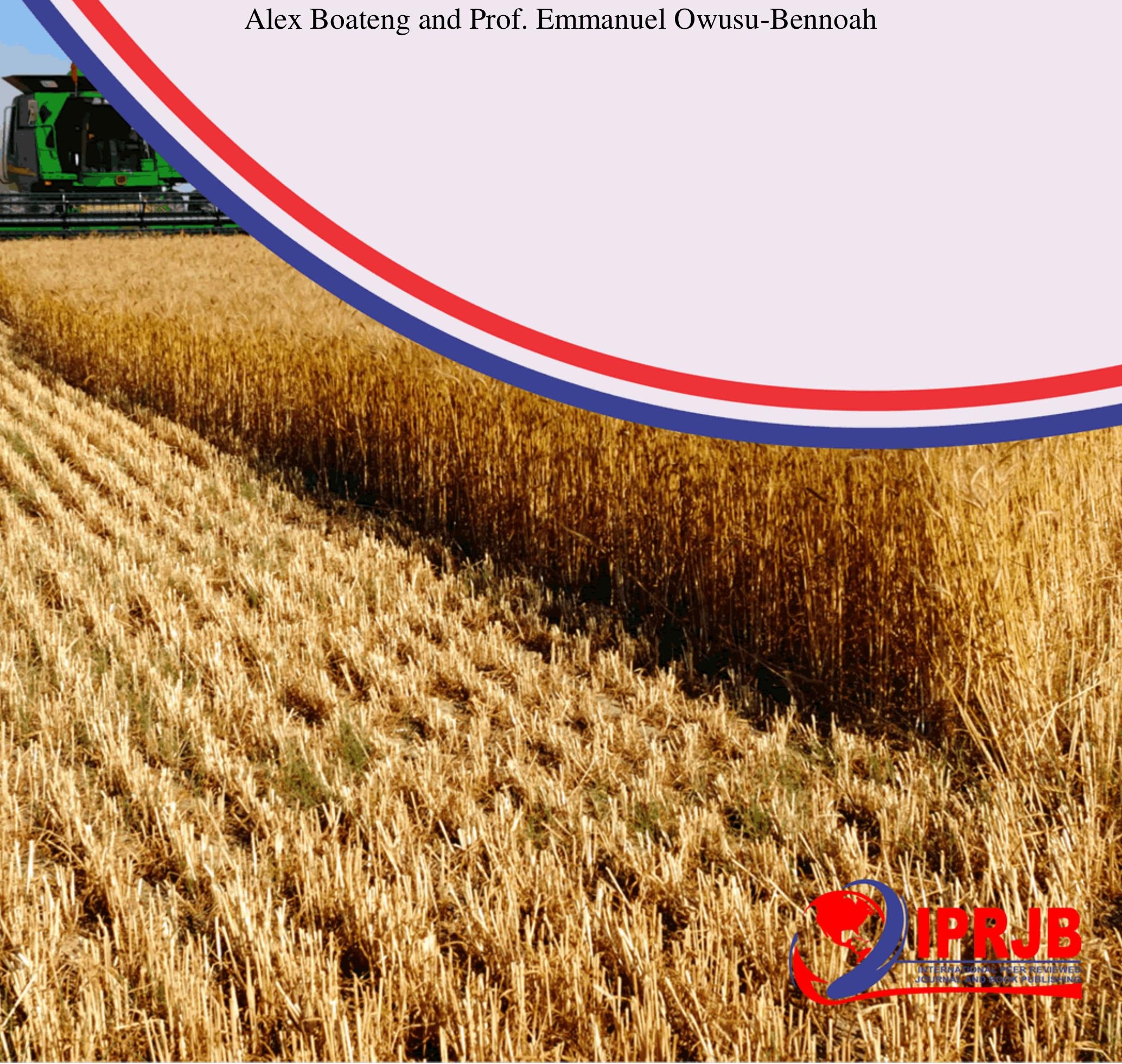




\title{
EFFECTS OF PHOSPHORUS AVAILABILITY ON NODULATION AND NITROGEN UPTAKE BY THREE LEGUME CROPS IN TWO GHANAIAN SOILS
}

\author{
${ }^{1 *}$ Alex Boateng \\ Mount Mary College of Education \\ Corresponding Author Email: kabtsara@gmail.com \\ ${ }^{2}$ Prof. Emmanuel Owusu-Bennoah \\ Lecturer, Soil Science Department: University of Ghana
}

\begin{abstract}
Purpose: A greenhouse study of Soybean, Cowpea and Pigeon Pea was made at University of Ghana, to determine the effects of phosphorus availability on nodulation and nitrogen uptake by the afore mentioned legumes in two Ghanaian soils, Adenta and Nzema series.

Methodology: Three P rates of 0mg, 50mg and 100mg P of TSP and TPR were applied to a kilogram of soil per pot in two soil series. The pots were arranged using Randomized Complete Block Design. Genstat ${ }^{\mathrm{R}}$ was used to do the statistical analysis.

Findings: The results from this study showed that with or without Triple Super Phosphate (TSP) or Togo Phosphate Rock (TPR), soybean did not form nodules in the Nzema soil but nodulated with TSP application in the Adenta soil. The absence of nodulation even with high $\mathrm{P}$ from TSP by soybean in Nzema soil is surprising but the observation in the Nzema soil may be attributed to the absence of soybean Rhizobium cells or insignificant numbers of these rhizobia. The results of the present data indicated that treatments with higher $\mathrm{P}$ application gave higher $\mathrm{N}$ uptake and showed the link among $\mathrm{P}$ application, high nodule dry weight, and $\mathrm{N}$ uptake. The improvement in the dry matter yield of pigeon pea and cowpea on Adenta soil and soybean on the Nzema soil at $\mathrm{TPR}_{50}$ and $\mathrm{TPR}_{100}$ show the importance of $\mathrm{P}$ application to dry matter yield of legumes. Significant difference that was shown by cowpea on Nzema soil could be attributed to the ability of the crop to desorp P from sparingly available P sources through exudation of high amounts of organic acid anions, mainly citrate.
\end{abstract}

Unique contributions to theory, practice and policy: In the soil, Rhizobium species must recognize their specific host before nodulation may take place and the absence of the appropriate Rhizobium species with the introduction of a legume into a given soil may result in no or poor nodulation. Low P availability is a challenge for crop species to nodulate since the rhizobia responsible for nitrogen fixation have a high $\mathrm{P}$ requirement. The toxicity of Aluminum to rhizobia may be due to inhibition of DNA replication because of binding of Aluminum to DNA. One factor that could have accounted for the better nodulation in soil is the higher acidity. The optimum $\mathrm{pH}$ for effective rhizobia growth in soils is between $\mathrm{pH} 6$ and 7.

Key words: Rhizobia, Rhizobium, Nzema, Adenta, Nodules, Aluminum, desorp, 


\section{I.0 1NTRODUCTION}

Farmers in Africa, particularly Ghana, know the importance of legumes, especially grain legumes. They include them in their cropping systems although not because they know that legumes fix atmospheric nitrogen. Their reason is that legumes are a great source of protein for their families and also stabilize yield (Akinyele 1991; Sanginga et al, 2001).

The production and utilization in Ghana have improved tremendously over the years and has become the second source of protein after egg. Though there have been several improved varieties made available to farmers by the Crop Research Institute not much is realized by these farmers due to low P status of the soil. One of the major problems that have constrained the development of an economically successful sustainable agriculture in Sub-Saharan Africa (SSA) is prevalent poor soil fertility for crop production.

Phosphorus has long been considered as one of the most limiting nutrients for plant growth from the tropics to arid ecosystems (CIAT 1992; Magadlela et al, 2016; Pẻrez-Fernảndez et al. 2017). Many of the agricultural soils in the tropical and subtropical regions are low in both total and available phosphorus (P), which is an essential plant nutrient (Bationo et al., 1998; Vanlauwe et al., 2002). Phosphorus is critically needed to improve soil fertility for crop production in large areas of developing countries due to $\mathrm{P}$ fixation by $\mathrm{Fe}$ and $\mathrm{Al}$ oxides (Sample et al., 1980).

Soils in West Africa, and Ghana in particular, are strongly weathered and inherently poor in fertility (Sanchez, 1976; Buresh et al. 1997; Mokwunye et al., 1986). The deficiency in most of these soils is so acute that plants sometimes fail to grow as soon as the $\mathrm{P}$ in the seed is exhausted (Wild \& Jones, 1986). On acid soils the problem is more severe as the applied P is converted to unavailable forms due to reactions with iron and aluminium oxides (Mokwunye et al 1986; Warren, 1992; Owusu-Bennoah et al. 1997; Abekoe \& Sahrawat, 2001). Acquaye \& Oteng (1972) reported a mean total inorganic P content of 26 savanna soils as $81 \mathrm{mg} \mathrm{P} \mathrm{kg}^{-1}$, $93 \mathrm{mg} \mathrm{P} \mathrm{kg}^{-1}$ for 8 forest/savanna integrate soils and $124 \mathrm{mg} \mathrm{P} \mathrm{kg}^{-1}$ for 14 forest soils. OwusuBennoah \& Acquaye (1989) also reported that the total P values of topsoil of four modal forest soils ranged from 54 to $243 \mathrm{mg} \mathrm{P} \mathrm{kg}^{-1}$ soil. Total $\mathrm{P}$ content of the $0-22 \mathrm{~cm}$ layer of profiles of nine typical savanna soils ranged from 50 to $173 \mathrm{mg} \mathrm{P} \mathrm{kg}^{-1}$ soil, whereas organic $\mathrm{P}$ values ranged from 36 to $100 \mathrm{mg} \mathrm{P} \mathrm{kg}^{-1}$ soil (Owusu-Bennoah \& Acquaye, 1989). Total P content of 67 top soils from high-grass savanna zone of Ghana averaged $134 \mathrm{mg} \mathrm{P} \mathrm{kg}^{-1}$ (Nye \& Bertheux, 1957).

The phenomenon of sorbed $\mathrm{P}$ is common in highly weathered soils (Ultisols and Oxisols) and in some volcanic soils with high amount of amorphous compounds. White (1981) attributed P adsorption in highly weathered soils to clay content, free aluminium (Al) and iron (Fe) oxides, $\mathrm{pH}$, ionic strength of soil solution, mineralogy of soil as well as organic matter. Other studies have also attributed high sorption in tropical soils to factors such as oxides and hydroxides of Al and Fe (Torrent, 1987; Owusu-Bennoah \& Acquaye, 1989; Pena \& Torrent, 1990). In highly weathered soil where $\mathrm{Al}$ and $\mathrm{Fe}$ oxyhydroxides are generated, formation of $\mathrm{Al}$ and $\mathrm{Fe}$ phosphates which are not readily soluble and available for plant uptake occurs.

In the particular case of leguminous plants, it has been proved that phosphorus addition to plants growing in poor soils increases noticeably their nodulation and biomass production (Robson 1983; Magadlela et al, 2016; Pẻrez-Fernảndez et al. 2017). When $\mathrm{P}$ is limiting, nodules can act as a sink for $\mathrm{P}$ that is later compensated with a greater biological nitrogen fixation (Vadez et al, 1999; Mortimer et al, 2013). Nodules number increases with addition of 
P, implying more efficient nitrogen fixation (Israel 1987). Strains of rhizobia differ markedly in tolerance to phosphorus deficiency (jakobsen1985). Leguminous species differ in their phosphorus requirement for growth from 0.8 to $3 \mathrm{mM}$ (Magadlela et al.2015).

Phosphorus appear essential for both nodulation, $\mathrm{N}_{2}$ fixation; hence $\mathrm{N}_{2}$ fixation-dependent plants will require more $\mathrm{P}$ than those supplied with combined nitrogen (Stevens et al. 2019). Nodulation, N2 fixation and plant performance are directly related to the P supply (Vardien et al, 2014; Magadlela et al, 2016; Pẻrez-Fernảndez et al. 2017). Nodulation and N2 fixation increase after addition of $\mathrm{P}$ in several leguminous species and it might be modified by the water status of both the plant and the soil (Vasileva \& Kostov, 2002; Magadlela et al., 2015, 2016).

Soils in Ghana are low in both total and available P. Though lot of researches have been done in many parts of the country regarding effect of $P$ rates on several crops, not same can be said about effect of $\mathrm{P}$ rates on nodule formation with its consequential effects of boosting grain legumes on many soil series in the country, particularly the Nzema and Adenta soil series. It is therefore imperative that much research is carried out to establish rates of $\mathrm{P}$ that will boost production of grains legumes in order to improve the health of our people, hence this research. I hypothesize that adding and increasing the rates of phosphorus (TSP or TPR) will improve nodulation, nodule dry weight and nitrogen fixation and uptake

In this instance the study was carried out to

1. Find out the behaviour of some legume crops in two soil series with relatively low phosphorus at $0 \mathrm{mgP}$ rate.

2. Find out the rate of P of Triple Super Phosphate and Togo Phosphorus Rock that will improve nodulation and nitrogen fixation and uptake.

\subsection{RESEARCH METHODOLOGY}

\section{Soils and sampling}

Five representative surface samples from the plough layer $(0-15 \mathrm{~cm})$ of each of two the soil series, Adenta and Nzema, representing the Coastal savanna and Forest zones of Ghana, were taken. The samples were air-dried, crushed and passed through a $2 \mathrm{~mm}$ sieve to obtain the fine earth fraction.

\section{Adenta series}

The Adenta series has been classified as Paleustalf and Hypedystric Acrisol according to USDA (1999, 2003) and ISSS-ISRIC-FAO (WRB) (1998) respectively and it occupies the middle slope position on the landscape of the Legon hill in the Greater Accra of Ghana. It is a well-drained soil. Baah (2010) also classified it as Paleustalf and it is acidic with pH of 5.8 in the surface horizon but increases in acidity with depth. The mean annual temperature and rainfall is $27^{\circ} \mathrm{C}$ and $800 \mathrm{~mm}$ respectively

\section{Nzema series}

The Nzema series (Ultisol), is described as Paleustalf (USDA 1999), was sampled from the Agricultural Research Station, Kade (6043 N: 1036 W) in the Eastern Region of Ghana. It also occupies the middle slope position of the catena with mean annual rainfall ranging from 1500 to $2000 \mathrm{~mm}$. It is found in a semi-deciduous rainforest and it is acidic with $\mathrm{pH}$ ranging from 4.9-5.2. It is a moderately-well drained soil. 


\section{Soil physical analysis}

\section{Particle size analysis}

Particle size distribution was carried out by the Bouyoucos method (1962). Forty grams sample of a $2 \mathrm{~mm}$ sieved soil was weighed into a beaker and $100 \mathrm{ml}$ of $5 \%$ Calgon (Sodium Hexametaphosphate) solution was added. The suspension was shaken on a mechanical shaker for $2 \mathrm{~h}$. The suspension was thereafter transferred into a graduated sedimentation cylinder and distilled water added to bring the level to the 1litre mark. A plunger was used to stir the suspension vigorously by moving the plunger in and out several times and the first and second hydrometer readings were taken at $5 \mathrm{~min}$ and $5 \mathrm{~h}$ from the time of mixing the suspension, representing silt + clay and clay respectively. The sand fraction was obtained by decanting the suspension from the sedimentation cylinder and recording the dried weight after it had been oven-dried for two (2) days and cooled in a dessicator. Blank hydrometer readings of Sodium Hexametaphosphate solution at 5 min and 5 hrs were taken.

The percentages of the various soil separates were then determined as follows:

a) Silt $(\%)+$ Clay $(\%)=$ Corrected hydrometer reading at $5 \mathrm{~min} \times 100 /$ sample weight $(\mathrm{g})$

b) Clay $(\%)=$ Corrected hydrometer reading at $5 \mathrm{~h} \times 100 /$ sample weight $(\mathrm{g})$

c) Silt $(\%)=a-b$

d) Sand $(\%)=100-\mathrm{a}$

Texture of the soil was determined using the USDA textural triangle.

\section{Field capacity determination}

One $\mathrm{kg}$ of each of the soils was weighed in triplicate and was saturated with water and allowed to drain in plastic pots for two days in an open air. Sub samples were taken from the wet soil and oven-dried at a temperature of $105^{\circ} \mathrm{C}$ for $24 \mathrm{~h}$ to constant weight and final weight recorded. The difference between the moist weight and the dry weight was taken as the mass of the water at field capacity.

$\%$ Water content at field capacity $=\underline{(\text { Weight of moist soil })-(\text { Weight of oven-dried soil }) \times 100}$

(Weight of oven-dried soil)

\section{Soil Chemical Analyses}

\section{Soil pH}

Soil $\mathrm{pH}$ was determined in both distilled water and $0.01 \mathrm{M}$ calcium chloride using a MV 88 Pracitronic $\mathrm{pH}$ glass electrometer. Ten grams $(10 \mathrm{~g})$ of the soil sample was weighed into a 50 $\mathrm{ml}$ beaker and $10 \mathrm{ml}$ of distilled water was added. The soil-liquid suspension was then stirred several times for $30 \mathrm{~min}$ and allowed to stand for most of the suspended clay to settle out. Using buffer solutions of $\mathrm{pH} 4.0$ and 7.0, the $\mathrm{pH}$ electrometer was standardized. The standardized electrode was then inserted into the supernatant of the suspension to measure the $\mathrm{pH}$ of the soil sample. The procedure was repeated with $20 \mathrm{~g}$ of soil and $40 \mathrm{ml}$ of $0.01 \mathrm{M} \mathrm{CaCl}_{2}$. 


\section{Organic carbon}

The wet combustion method of Walkley and Black (1934) was used to determine the organic carbon contents of the soils. Ten millimeters of $0.167 \mathrm{M}$ potassium dichromate $\left(\mathrm{K}_{2} \mathrm{Cr}_{2} \mathrm{O}_{7}\right)$ solution and $20 \mathrm{ml}$ concentrated sulphuric acid $\left(\mathrm{H}_{2} \mathrm{SO}_{4}\right)$ were added to $0.5 \mathrm{~g}$ soil (which had been passed through a $0.5 \mathrm{~mm}$ sieve) in an Erlenmeyer flask. The flask was then swirled to ensure full contact of the soil with the solution after which it was allowed to stand for $30 \mathrm{~min}$. The unreduced $\mathrm{K}_{2} \mathrm{Cr}_{2} \mathrm{O}_{7}$ remaining in solution after the oxidation of the oxidizable organic material in the soil sample was titrated against $0.2 \mathrm{M}$ ferrous ammonium sulphate solution after adding $200 \mathrm{ml}$ of distilled water, $10 \mathrm{ml}$ of orthophosphoric acid and $2 \mathrm{ml}$ of barium diphenylamine sulphate indicator till colour changed from a brown colour to a bright green end point.

The percent organic carbon was calculated as:

$\% \mathrm{C}=\underline{0.3[10-(\mathrm{XN})] \times 1.33}$

$\mathrm{W}$

Where: $\mathrm{X}=\mathrm{ml}$ of $\mathrm{Fe}\left(\mathrm{NH}_{4}\right)_{2}\left(\mathrm{SO}_{4}\right)_{2}$ required for the titration

$\mathrm{N}=$ normality of $\mathrm{Fe}\left(\mathrm{NH}_{4}\right)_{2}\left(\mathrm{SO}_{4}\right)_{2}$

$\mathrm{W}=\mathrm{Weight}$ of soil sample

\section{Available $\mathbf{P}$ determination}

Available phosphorus was determined using Bray 1 method. Five grams (5 g) of soil was weighed into a centrifuge bottle and $50 \mathrm{ml}$ of Bray 1 solution $\left(0.03 \mathrm{~N} \mathrm{NH}_{4} \mathrm{~F}+0.025 \mathrm{~N} \mathrm{HCl}\right)$ was added. The suspension was shaken for about $5 \mathrm{~min}$ on a mechanical shaker and thereafter was made to stay overnight for the suspension to settle after which the suspension was filtered through a No. 42 Whatman filter paper into a $100 \mathrm{ml}$ volumetric flask and made up to the volume. Available phosphorus in the filtrate was determined using molybdate-ascorbic acid method of Watanabe and Olsen (1965) as follows:

Five (5) $\mathrm{ml}$ aliquots of the filtrate from the Adenta soil and $10 \mathrm{ml}$ aliquots of the filtrate from Nzema soil were taken into a $50 \mathrm{ml}$ volumetric flask in duplicates. The $\mathrm{pH}$ was adjusted using P-nitrophenol indicator and neutralized with a few drops of $4 \mathrm{M} \mathrm{NH}_{4} \mathrm{OH}$ until the solution turned yellow. The solutions were diluted to $40 \mathrm{ml}$ with distilled water after which $8 \mathrm{ml}$ of a mixture of $12 \mathrm{~g}$ ammonium molybdate, $0.29 \mathrm{~g}$ potassium antimony tartrate, $140 \mathrm{ml}$ concentrated $\mathrm{H}_{2} \mathrm{SO}_{4}$ and $1.056 \mathrm{~g}$ of ascorbic acid (reagent $\mathrm{B}$ ) were added. The solutions were mixed thoroughly by shaking and allowing standing for $15 \mathrm{~min}$ for the colour to stabilize (The colour changed to blue of different shades depending on the concentration of the $\mathrm{P}$ in each sample. A blank was prepared with distilled water and $8 \mathrm{ml}$ of reagent $B$. The spectrophotometer was calibrated using $25 \mathrm{mg} \mathrm{L}^{-1}$ standard $\mathrm{P}$ solution in the same manner as above. The intensity of the blue colour was measured using the Philips PU 8620 spectrophotometer at a wavelength of $712 \mathrm{~nm}$. The $\mathrm{P}$ concentration was read on the spectrophotometer and calculated as follows:

$\mathrm{P}\left(\mathrm{mg} \mathrm{kg}^{-1}\right)$ soil $=(\underline{\text { Spectrophotometer reading-blank reading }) \mathrm{x} \text { volume of extract }}$ 


\section{Total P determination}

Total $\mathrm{P}$ was determined by digesting $2 \mathrm{~g}$ of $0.5 \mathrm{~mm}$ sized soil with $25 \mathrm{ml}$ of a mixture of concentrated $\mathrm{HNO}_{3}$ and $60 \% \mathrm{HCIO}_{4}$ in the ratio 2:3. The solution was heated on a digestion rack until the solution became colourless. The digest was cooled, diluted and filtered through a Whatman filter paper No. 42 into $250 \mathrm{ml}$ volumetric flask. The samples were analyzed for phosphorus using Murphy and Riley method (1962). The colour intensity was read using a spectrophotometer at wavelength of $712 \mathrm{~nm}$.

$\mathrm{P}$ was calculated using the formula:

$\mathrm{P}(\mathrm{mg} / \mathrm{kg})=\underline{(\mathrm{Sp} . \text { Reading-Blank }) \times \text { Vol. of extract }}$

Vol. of aliquot $\mathrm{x}$ weight of soil

\section{Total nitrogen determination}

Half of a gram $(0.5 \mathrm{~g})$ of soil was weighed into a $250 \mathrm{ml}$ kjedahl flask and a tablet of digestion accelerator, selenium catalyst, was added followed by $5 \mathrm{ml}$ concentrated $\mathrm{H}_{2} \mathrm{SO}_{4}$. The mixture was digested until the digest became clear. The flask was then cooled and its content transferred into a $100 \mathrm{ml}$ volumetric flask with distilled water and quantitatively made up to volume. A $5 \mathrm{ml}$ aliquot of the digest was taken into a Markhan distillation apparatus. Five ml of $40 \% \mathrm{NaOH}$ solution was added to the aliquot and the mixture distilled. The distillate was collected in $5 \mathrm{ml}$ of $2 \%$ boric acid. Three drops of a mixed indicator containing methyl red and methylene blue were added to the distillate in a 50ml Erlenmeyer flask and then titrated against $0.01 \mathrm{M} \mathrm{HCl}$ acid solution (Bremner, 1965). The \% nitrogen was calculated as:

$\% \mathrm{~N}=$ Molarity of $\mathrm{HCl} \times$ Titre volume $\mathrm{x} 0.014$ x volume of extractant $\mathrm{x} 100 \ldots \ldots$

Weight of soil sample $\mathrm{x}$ volume of aliquot

Where $0.014=$ milliequivalent of nitrogen

\section{Exchangeable bases}

Ten grams of each soil sample was weighed into a $100 \mathrm{ml}$ centrifuge tube and $20 \mathrm{ml}$ of $1 \mathrm{M}$ $\mathrm{NH}_{4} \mathrm{OAc}$ at $\mathrm{pH} 7.0$ solution was added. The bottles with their contents were shaken for $1 \mathrm{~h}$, centrifuged at $1000 \mathrm{rpm}$ for $10 \mathrm{~min}$ and filtered through a Whatman No. 42 filter paper. The ammonium saturated soil was washed three times with $95 \%$ ethanol by shaking for 15 min on a mechanical shaker and then centrifuged at $1000 \mathrm{rpm}$ for $10 \mathrm{~min}$. Calcium and magnesium in the extract were determined using Atomic Absorption Spectrometry. Potassium and sodium were determined by flame photometry.

$\% \mathrm{Ca}=($ AAS Reading/1000) $\times(100 / 1000) \times(100 / \mathrm{wt})$

$\mathrm{AAS}=$ atomic absorption spectrometry, to get $\mathrm{mg} / \mathrm{kg}$ multiply \%Ca by 10000 
International Journal of Agriculture

ISSN 2520-4629X (Online)

Vol.6, Issue 1, No.2 pp 20 - 38, 2021

$\% \mathrm{~K}=($ ASS Reading $\mathrm{x}$ Extract $\mathrm{x} 100) / \mathrm{wt}$ of soil $\mathrm{x} 10^{6}$

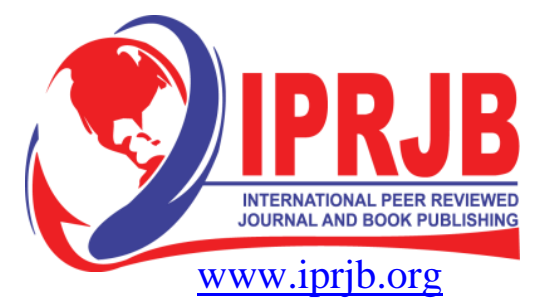

\section{Exchangeable acidity $\left(\mathrm{Al}^{3+,} \mathrm{H}^{+}\right)$and ECEC}

Twenty-five $\mathrm{mL}$ of $1 \mathrm{M} \mathrm{KCl}$ was added to $10 \mathrm{~g}$ of soil sample in a $250 \mathrm{~mL}$ conical flask. The content was mixed by swirling and then allowed to stand for $30 \mathrm{~min}$. The suspension was filtered through a Whatman No. 42 filter paper into a volumetric flask. The soil was consecutively leached with five (5) batches of $25 \mathrm{ml} 1 \mathrm{M} \mathrm{KCl}$ to a total volume of about $150 \mathrm{ml}$. Four drops of phenolphthalein were added to the leachate and titrated against $0.1 \mathrm{M}$ $\mathrm{NaOH}$ to the first permanent pink endpoint. Potassium chloride extractable exchangeable acidity was calculated as:

$\mathrm{C}$ mol kg${ }^{-1} \mathrm{KCl}$ acidity $=(\mathrm{ml} \mathrm{NaOH}$ Sample- $\mathrm{ml} \mathrm{NaOH}$ blank $)$ x M x $100 /$ Sample $(\mathrm{g})$

Where, $\mathrm{M}$ is Molarity of $\mathrm{NaOH}$.

For estimation of $\mathrm{Al}^{3+}$ and $\mathrm{H}^{+}$, the titre for $\mathrm{NaOH}$ was recorded; $10 \mathrm{ml}$ of $1 \mathrm{M} \mathrm{NaF}$ was added to the $\mathrm{NaOH}$ and titrated with $0.1 \mathrm{M} \mathrm{HCl}$ until the pink colour disappeared. The solution was then allowed to stand for about $30 \mathrm{~min}$ and additional $\mathrm{HCl}$ added to clear endpoint (Thomas, 1982). The effective cation exchange capacity (ECEC) was obtained by summation of the exchangeable bases and exchangeable acidity (Coleman et al., 1959). Percent aluminium saturation was calculated as:

(Exchangeable Al) / ECEC * 100.

\section{The Greenhouse Experiment}

Nzema and Adenta series were the two soil series used for the experiment. One hundred and eight (108) plastic pots were arranged in greenhouse benches at the University of Ghana's greenhouse. Each of the pots was filled with a kilogram of soil each from one soil series (Adenta or Nzema) mixed with acid-washed sea sand. The sand was first washed continuously with tap water for 7 days after which it was thoroughly washed again with distilled water to get rid of the sea water. Silver nitrate solution was used to check the level of saltiness in the sand intermittently. Concentrated Hydrochloric acid $(\mathrm{HCl})$ solution was poured onto the sand and was made to stand for 3 days to dissolve the $\mathrm{CaCO}_{3}$ concretions and other organic materials in the sand. The sand was further washed thoroughly with distilled water for four continuous/consecutive days to get rid of the $\mathrm{HCl}$ after which the sand was dried in the sun for 2 days. One $\mathrm{kg}$ of the soil and acid-washed sand were weighed into each of the $15.2 \mathrm{~cm}$ diameter pots.

Two P sources, Togo PR and Triple superphosphate (TSP) were applied at rates of $0 \mathrm{mg} \mathrm{P} \mathrm{kg}$ 1, $50 \mathrm{mg} \mathrm{P} \mathrm{kg}{ }^{-1}, 100 \mathrm{mg} \mathrm{P} \mathrm{kg}^{-1}$ soil equivalent to $0 \mathrm{~g}, 0.3125 \mathrm{~g}$ and $0.625 \mathrm{~g} \mathrm{PR}$ and $0 \mathrm{~g}, 0.25 \mathrm{~g}$ and $0.50 \mathrm{~g}$ TSP. The rates were based on the percent total $\mathrm{P}$ content in both sources. The total $\mathrm{P}$ content of the TSP is $20 \%$ while that of Togo PR is $16 \%$ (using $1 \%$ citric acid). Three (3) test crops were used, namely; Soybean \{Glycine max-(TGX 1912-13F)\}, Cowpea \{Vigna unguiculata (Black eye)\}, Pigeon pea $\{$ Cajanus cajan $\}$. The treatments were replicated three times giving a total of 108 experimental units ( 3 crops x 2 sources of soil x 3 levels of $\mathrm{P} \times 2$ sources of $\mathrm{P}$ x 3 replications). The soil in each pot, except those for control treatments, was 
transferred to a bigger pot and a weighed amount of the $\mathrm{P}$ fertilizer was added, thoroughly mixed with the soil and returned to their respective pots.

The pots were laid out as a randomized complete block design with the pots re-randomized within each block and then rotated weekly to minimize uneven environmental effects within the greenhouse. Each pot received five seeds of the test crop and was thinned to two plants after emergence. Distilled water was added daily to maintain the soil at 45-60\% field capacity. Each pot containing a legume crop was supplied with basal nitrogen application of $50 \mathrm{mg} \mathrm{N}$ $\mathrm{kg}^{-1}$ equivalent to $0.1 \mathrm{~g}$ urea. Potassium Sulphate was supplied to all pots at a rate of $150 \mathrm{mg}$ $\mathrm{K} \mathrm{kg}^{-1}$. This application was done 7 days after seedlings had emerged. The plants were grown for 42 days after which the tops of the crops were harvested. The crops were cut at the soil level and immediately the fresh weight of the shoot was taken. The harvested plants were thoroughly washed with distilled water to remove any soil particle on them. The washed plants were dried on a pad or tissue paper and placed in paper bags and dried in an oven at $70^{\circ} \mathrm{C}$ for $72 \mathrm{~h}$ to constant weight. Dry weights of the nodules were similarly taken. The dried plant materials were ground to pass through a $1 \mathrm{~mm}$ sieve after which they were stored for subsequent $\mathrm{N}$.

\section{Digestion of plant material}

One-tenth gram $(0.1 \mathrm{~g})$ of the plant sample was weighed into a $25 \mathrm{ml}$ flask and $5 \mathrm{ml}$ of concentrated sulphuric acid was added after which the flasks with its contents were each swirled intermittently to facilitate contact between the sample and the sulphuric acid. The flask was allowed to stand overnight for the sulphuric acid to dissolve the plant sample entirely. Thereafter, each solution was heated for some time after which Hydrogen Peroxide $\left(\mathrm{H}_{2} \mathrm{O}_{2}\right)$ was added until the solution became clear. Distilled water was added and the solutions were allowed to stand overnight to cool and settle after which they were decanted into $100 \mathrm{ml}$ flask. The total nitrogen $(\mathrm{N})$ was determined by the macro-kjedahl method (Bremner, 1965).

\section{Statistical Analysis}

Data were collected, averaged and analyzed after which ANOVA was performed on them using GenStat $\left(9^{\text {th }}\right.$ edition) software.

\subsection{RESULTS}

\section{Physico-chemical characteristics of the soils}

Table 1 gives the physical and chemical characteristics of the soils used for the study. According to the soil particle size analysis, the topsoil of Nzema soil can be classified as sandy clay loam while that of Adenta soil is clay to sandy clay. The results showed a sand content of $550 \mathrm{~g} / \mathrm{kg}$ in Nzema, which was higher than the $475 \mathrm{~g} / \mathrm{kg}$ in Adenta. The silt content was also higher in Nzema $(125 \mathrm{~g} / \mathrm{kg})$ than in Adenta $(75 \mathrm{~g} / \mathrm{kg})$ while the clay content was lower in Nzema $(325 \mathrm{~g} / \mathrm{kg})$ than in Adenta $(450 \mathrm{~g} / \mathrm{kg})$. The relative composition of Nzema and Adenta followed: Sand $>$ Clay $>$ Silt .The analysis also indicated that Nzema was strongly acidic with $\mathrm{pH}$ of 4.4 (1:1 soil: water) while Adenta was slightly acidic (pH 6.3).

The organic carbon content of Nzema series $(19.6 \mathrm{~g} / \mathrm{kg}$ ) was higher than that of Adenta series $(17.5 \mathrm{~g} / \mathrm{kg})$. Total nitrogen was found to be higher in Nzema soil $(2.8 \mathrm{~g} / \mathrm{kg})$ than the Adenta soil $(2.3 \mathrm{~g} / \mathrm{kg})$. Soil extractable Bray-1 in Nzema soil $\left(7.45 \mathrm{mg} \mathrm{P} / \mathrm{kg}^{-1}\right)$ was lower than the Adenta soil (16.1mg P/kg). In general, exchangeable $\mathrm{Ca}^{2+}$ and $\mathrm{Mg}^{2+}$ cations were higher in the 
International Journal of Agriculture

ISSN 2520-4629X (Online)

Vol.6, Issue 1, No.2 pp 20 - 38, 2021

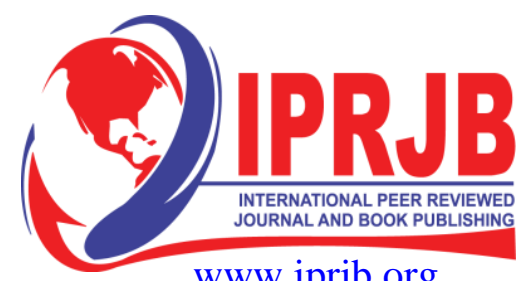

Coastal savanna soil (Adenta) than the Nzema soil in the semi-deciduous forest zone, as shown in Table 1. The Nzema soil had higher exchangeable acidity than the Adenta soil.

Table 1. Some physical and chemical properties of the topsoil $(0-15 \mathrm{~cm})$ of the Nzema and Adenta series

Properties

Sand $\left(\mathrm{gkg}^{-1}\right)$

Silt $\left(\mathrm{gkg}^{-1)}\right.$

Clay $\left(\mathrm{gkg}^{-1}\right)$

$\mathrm{pH}$ (water)

$\mathrm{pH}\left(0.01 \mathrm{M} \mathrm{CaCl}_{2}\right)$

Total C $\left(\mathrm{gkg}^{-1}\right)$

Organic matter $\left(\mathrm{gkg}^{-1}\right)$

Available P $\left(\mathrm{mgkg}^{-1}\right)$
Total N $\left(\mathrm{gkg}^{-1}\right)$

Nzema series

550

125

325

4.4

4.2

19.6

33.7

Exchangeable bases $\left(\mathrm{cmol}(+) / \mathrm{kg}^{-1}\right)$

$\mathrm{Ca}^{2+}$

$\mathrm{Mg}^{2+}$

$\mathrm{K}^{+}$

0.30

0.40

$\mathrm{Na}$

0.38

0.36

Exchangeable acidity $\left(\mathrm{cmol}(+) / \mathrm{kg}^{-1}\right.$

$\mathrm{Al}^{2+}$

0.40

$\mathrm{H}^{+}$

1.38

ECEC

(\%) Al saturation 5.28

\section{Effect of TSP and TPR application rates on Nodulation}

Tables 2-7 show the effects of TSP and TPR application on nodule number, nodule dry weight and $\mathrm{N}$ uptake of the legume crops in the two soils. Soybean did not nodulate at all in the Nzema soil with both TSP and TPR application and did not nodulate as well on Adenta soil with TPR application (Table 3 and 6) but nodulated with TSP application in Adenta soil. 
Cowpea and pigeon pea did not produce any nodule from the control treatments on Nzema soil (Table 2 and 6) but nodules were formed on cowpea in the control pots on the Adenta soil (Table 5). When the P sources were applied to the Nzema soil cowpea produced nodules.

There were significant differences $(\mathrm{p}<0.05)$ in the number of nodules formed by cowpea and pigeon pea in both soils. Phosphorus application significantly $(\mathrm{p}<0.05)$ increased the nodule numbers on cowpea and pigeon pea with increase in $\mathrm{P}$ rates in both soils. In general the nodule numbers were greater in water-soluble Phosphorus fertilizer (TSP) treated soil than the unreactive PR (Table 5-7)

As shown in Tables 2-7, even though pigeon pea produced a lot of nodules upon $\mathrm{P}$ application to the two soils, cowpea and soybean in Adenta produced larger nodules and this was seen in the dry matter weight of their nodules. Pigeon pea produced many but small size nodules. Cowpea showed significant differences in the nodule dry matter among the different $\mathrm{P}$ rates of TSP application in the two soil series. On the whole, Adenta soil produced more and larger nodules than with the Nzema soil. This study also revealed that TPR improved nodule numbers and dry matter weight of cowpea and pigeon pea in the Adenta soil than in the Nzema soil (Table 3-6).

\section{Effect of TSP and TPR application rates on $\mathrm{N}$ uptake}

Triple superphosphate (TSP) application resulted in significant $(\mathrm{p}<0.05)$ effect on nitrogen uptake or content in the various leguminous plant species (Table 2-7). The effect was more than doubling in $\mathrm{P}$ uptake compared with the no P treatments. As shown in Table 2, 4 and 5, soybean and pigeon pea experienced similarly significant effect as by cowpea. Though soybean did not produce any nodule, there was significant effect on $\mathrm{N}$ uptake. Triple superphosphate had improved $\mathrm{N}$ uptake by soybean. The $\mathrm{N}$ uptake by soybean on Nzema soil when TPR was applied was higher than cowpea and pigeon pea on the two soils, though no nodulation occurred in the former crop species (Tables 2- 7). There was also a significant increase in $\mathrm{N}$ uptake in all the different plant species when TPR was applied to the two soils at $50 \mathrm{mg} \mathrm{P} /$ pot and above. (Tables 2-7). 
International Journal of Agriculture

ISSN 2520-4629X (Online)

Vol.6, Issue 1, No.2 pp 20 - 38, 2021

Table 2. Number of nodule/plant, dry weight and $\mathrm{N}$ uptake by cowpea under various rates of TSP and TPR application on Nzema soil

\begin{tabular}{lcccccc}
\hline Rates of & \multicolumn{2}{c}{ T S P } & \multicolumn{3}{c}{ T P R } \\
Application & Number of & Nodule dry & N content of & Number of & Nodule dry & N content of \\
(mg/pot) & nodules $/$ plant & weight $(\mathrm{mg} / \mathrm{kg})$ & plant $(\mathrm{mg} / \mathrm{kg})$ & . nodules $/$ plant & weight $(\mathrm{mg} / \mathrm{kg})$ & plant $(\mathrm{mg} / \mathrm{kg})$ \\
\hline 0 & $0.0 \mathrm{~b}$ & $0.0 \mathrm{~b}$ & $8.70 \mathrm{c}$ & $0.0 \mathrm{~b}$ & $0.0 \mathrm{c}$ & $8.70 \mathrm{bc}$ \\
50 & $11.0 \mathrm{a}$ & $10.0 \mathrm{a}$ & $48.50 \mathrm{~b}$ & $1.33 \mathrm{a}$ & $1.67 \mathrm{~b}$ & $13.80 \mathrm{~b}$ \\
100 & $13.33 \mathrm{a}$ & $18.3 \mathrm{a}$ & $100.40 \mathrm{a}$ & $1.67 \mathrm{a}$ & $3.33 \mathrm{a}$ & $20.40 \mathrm{a}$ \\
\hline LSD $(0.05)$ & 4.212 & 8.81 & & & & \\
CV $(\%)$ & 26.0 & 46.7 & 17.19 & 0.942 & 0.942 & 6.39 \\
SE & 2.108 & 4.41 & 8.60 & 47.1 & 28.3 & 22.40 \\
\hline
\end{tabular}

TSP= Triple superphosphate, TPR= Togo phosphate rock,

Means bearing the same letter are not significantly different.

Table 3. Number of nodule/plant, dry weight and N uptake by soybean under various rates of TSP and TPR application on Nzema soil

\begin{tabular}{|c|c|c|c|c|c|c|}
\hline \multirow{2}{*}{$\begin{array}{l}\text { Rates of } \\
\text { Application } \\
\text { (mg/pot) }\end{array}$} & \multicolumn{3}{|c|}{ T S P } & \multicolumn{3}{|c|}{ T P R } \\
\hline & $\begin{array}{l}\text { Number of } \\
\text { nodule/plant }\end{array}$ & $\begin{array}{c}\text { Nodule dry } \\
\text { weight (mg/kg) }\end{array}$ & $\begin{array}{l}\mathrm{N} \text { content of } \\
\text { plant }(\mathrm{mg} / \mathrm{kg})\end{array}$ & $\begin{array}{l}\text { Number of } \\
\text { nodule/plant }\end{array}$ & $\begin{array}{l}\text { Nodule dry } \\
\text { weight }(\mathrm{mg} / \mathrm{kg})\end{array}$ & $\begin{array}{l}\mathrm{N} \text { content of } \\
\text { plant }(\mathrm{mg} / \mathrm{kg})\end{array}$ \\
\hline 0 & 0.0 & 0.0 & $19.70 \mathrm{bc}$ & 0.0 & 0.0 & $19.70 \mathrm{ab}$ \\
\hline 50 & 0.0 & 0.0 & $31.60 \mathrm{~b}$ & 0.0 & 0.0 & $27.10 \mathrm{a}$ \\
\hline 100 & 0.0 & 0.0 & $62.20 \mathrm{a}$ & 0.0 & 0.0 & $36.70 \mathrm{a}$ \\
\hline $\operatorname{LSD}(0.05)$ & 0.0 & 0.0 & 12.76 & 0.0 & 0.0 & 10.61 \\
\hline CV (\%) & 0.0 & 0.0 & 16.90 & 0.0 & 0.0 & 19.10 \\
\hline SE & 0.0 & 0.0 & 6.39 & 0.0 & 0.0 & 5.31 \\
\hline
\end{tabular}

TSP= Triple superphosphate, TPR $=$ Togo phosphate rock,

Means bearing the same letter are not significantly different 
International Journal of Agriculture

ISSN 2520-4629X (Online)

Vol.6, Issue 1, No.2 pp 20 - 38, 2021

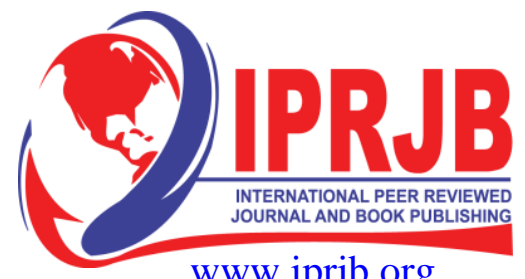

WwW.iprjb.org

Table 4. Number of nodule/plant, dry weight and $\mathrm{N}$ uptake of pigeon pea under various rates of TSP and TPR application in Nzema soil

\begin{tabular}{|c|c|c|c|c|c|c|}
\hline \multirow{2}{*}{$\begin{array}{l}\text { Rates of } \\
\text { Application } \\
\text { (mg/pot) }\end{array}$} & \multicolumn{3}{|c|}{ T S P } & \multicolumn{3}{|c|}{ T P R } \\
\hline & $\begin{array}{l}\text { Number of } \\
\text { nodules/plant }\end{array}$ & $\begin{array}{c}\text { Nodule dry } \\
\text { weight }(\mathrm{mg} / \mathrm{kg})\end{array}$ & $\begin{array}{l}\mathrm{N} \text { content of } \\
\text { plant }(\mathrm{mg} / \mathrm{kg})\end{array}$ & $\begin{array}{l}\text { Number of } \\
\text { nodules/plant }\end{array}$ & $\begin{array}{c}\text { Nodule dry } \\
\text { weight }(\mathrm{mg} / \mathrm{kg})\end{array}$ & $\begin{array}{l}\mathrm{N} \text { content of } \\
\text { plant }(\mathrm{mg} / \mathrm{kg})\end{array}$ \\
\hline 0 & $0.0 \mathrm{bc}$ & $0.0 \mathrm{a}$ & $7.03 c$ & $0.0 \mathrm{~b}$ & $Q 0 \mathrm{~b}$ & $7.03 \mathrm{bc}$ \\
\hline 50 & $2.8 \mathrm{~b}$ & $1.2 \mathrm{a}$ & $20.10 \mathrm{~b}$ & $1.83 \mathrm{a}$ & $1.07 \mathrm{a}$ & $9.61 \mathrm{~b}$ \\
\hline 100 & $18.0 \mathrm{a}$ & $5.7 \mathrm{a}$ & $53.90 \mathrm{a}$ & $2.33 \mathrm{a}$ & $1.41 \mathrm{a}$ & $17.28 \mathrm{a}$ \\
\hline$\overline{\mathrm{LSD}(0.05)}$ & 7.12 & 7.36 & 11.81 & 1.698 & 0.616 & 4.680 \\
\hline CV (\%) & 51.3 & 16.1 & 21.90 & 61.2 & 37.4 & 0.70 \\
\hline SE & 3.56 & 3.68 & 5.91 & 0.850 & 0.308 & 2.343 \\
\hline
\end{tabular}

TSP= Triple superphosphate, $T P R=$ Togo phosphate rock,

Means bearing the same letter are not significantly different.

Table 5. Number of nodule/plant, dry weight and $\mathrm{N}$ uptake of cowpea under various rates of TSP and TPR application in Adenta soil

\begin{tabular}{|c|c|c|c|c|c|c|}
\hline \multirow{2}{*}{$\begin{array}{l}\text { Rates of } \\
\text { Application } \\
\text { (mg/pot) }\end{array}$} & \multicolumn{3}{|c|}{ T S P } & \multicolumn{3}{|c|}{ T P R } \\
\hline & $\begin{array}{l}\text { Number of } \\
\text { nodule/plant }\end{array}$ & $\begin{array}{l}\text { Nodule dry } \\
\text { weight }(\mathrm{mg} / \mathrm{kg})\end{array}$ & $\begin{array}{l}\mathrm{N} \text { content of } \\
\text { plant }(\mathrm{mg} / \mathrm{kg})\end{array}$ & $\begin{array}{l}\text { Number of } \\
\text { nodule / plant }\end{array}$ & $\begin{array}{c}\text { Nodule dry } \\
\text { weight (mg/kg) }\end{array}$ & $\begin{array}{l}\mathrm{N} \text { content of } \\
\text { plant }(\mathrm{mg} / \mathrm{kg})\end{array}$ \\
\hline 50 & $15.33 b$ & $11.7 \mathrm{~b}$ & $77.30 \mathrm{~b}$ & $12.30 \mathrm{a}$ & $4.67 \mathrm{a}$ & $16.73 b$ \\
\hline 100 & $19.67 \mathrm{a}$ & $26.7 \mathrm{a}$ & $129.30 \mathrm{a}$ & $21.0 \mathrm{a}$ & $10.0 \mathrm{a}$ & $23.13 \mathrm{a}$ \\
\hline$\overline{\mathrm{LSD}(0.05)}$ & 3.586 & 7.48 & 44.52 & 26.19 & 5.84 & 3.993 \\
\hline
\end{tabular}

TSP $=$ Triple superphosphate, TPR= Togo phosphate rock,

Means bearing the same letter are not significantly different. 
International Journal of Agriculture

ISSN 2520-4629X (Online)

Vol.6, Issue 1, No.2 pp 20 - 38, 2021

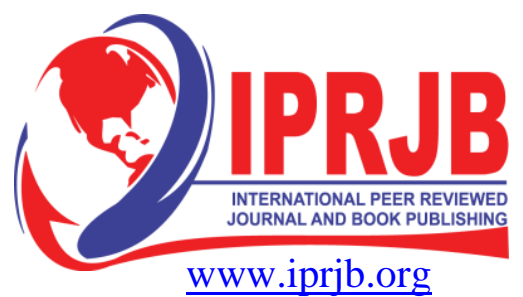

Table 6. Number of nodule/plant, dry weight and $\mathrm{N}$ uptake of soybean under various rates of TSP and TPR application in Adenta soil

\begin{tabular}{|c|c|c|c|c|c|c|}
\hline Rates of & & T S P & & & T P R & \\
\hline $\begin{array}{l}\text { Application } \\
\text { (mg/pot) }\end{array}$ & $\begin{array}{l}\text { Number of } \\
\text { nodules/plant }\end{array}$ & $\begin{array}{c}\text { Nodule dry } \\
\text { weight (mg/kg) }\end{array}$ & $\begin{array}{l}\mathrm{N} \text { content of } \\
\text { plant }(\mathrm{mg} / \mathrm{kg})\end{array}$ & $\begin{array}{l}\text { Number of } \\
\text { nodule/plant }\end{array}$ & $\begin{array}{l}\text { Nodule dry } \\
\text { weight }(\mathrm{mg} / \mathrm{kg})\end{array}$ & $\begin{array}{l}\mathrm{N} \text { content of } \\
\text { plant }(\mathrm{mg} / \mathrm{kg})\end{array}$ \\
\hline 0 & $0.0 \mathrm{~b}$ & $0.0 \mathrm{bc}$ & $17.30 \mathrm{bc}$ & 0.0 & 0.0 & $17.30 \mathrm{bc}$ \\
\hline 50 & $2.83 a$ & $5.7 \mathrm{~b}$ & $23.00 \mathrm{~b}$ & 0.0 & 0.0 & $17.40 \mathrm{~b}$ \\
\hline 100 & $2.83 \mathrm{a}$ & $17.0 \mathrm{a}$ & $62.50 \mathrm{a}$ & 0.0 & 0.0 & $27.90 \mathrm{a}$ \\
\hline $\operatorname{LSD}(0.05)$ & 0.952 & 1.55 & 31.83 & 0.0 & 0.0 & 9.71 \\
\hline CV $(\%)$ & 25.30 & 10.30 & 46.50 & 0.0 & 0.0 & 23.30 \\
\hline SE & 0.477 & 0.777 & 13.01 & 0.0 & 0.0 & 4.86 \\
\hline
\end{tabular}

$\mathrm{TSP}=$ Triple superphosphate, TPR= Togo phosphate rock,

Means bearing the same letter are not significantly different.

Table 7, Number of nodule/plant, dry weight and $\mathrm{N}$ uptake of pigeon pea under various rates of TSP and TPR application in Adenta soil

\begin{tabular}{|c|c|c|c|c|c|c|}
\hline \multirow{2}{*}{$\begin{array}{l}\text { Rates of } \\
\text { Application } \\
\text { (mg/pot) }\end{array}$} & \multicolumn{3}{|c|}{ T S P } & \multicolumn{3}{|c|}{ T P R } \\
\hline & $\begin{array}{l}\text { Number of } \\
\text { nodule/plant }\end{array}$ & $\begin{array}{l}\text { Nodule dry } \\
\text { weight (mg/kg) }\end{array}$ & $\begin{array}{l}\mathrm{N} \text { content of } \\
\text { plant }(\mathrm{mg} / \mathrm{kg})\end{array}$ & $\begin{array}{l}\text { Number of } \\
\text { nodules/plant }\end{array}$ & $\begin{array}{c}\text { Nodule dry } \\
\text { weight (mg/kg) }\end{array}$ & $\begin{array}{l}\text { N content of } \\
\text { plant }(\mathrm{mg} / \mathrm{kg})\end{array}$ \\
\hline 0 & $0.0 \mathrm{c}$ & $0.0 \mathrm{~b}$ & $11.03 \mathrm{bc}$ & $0.0 \mathrm{a}$ & $0.0 \mathrm{ab}$ & $11.03 \mathrm{bc}$ \\
\hline 50 & $15.7 \mathrm{~b}$ & $7.8 \mathrm{a}$ & $33.10 \mathrm{~b}$ & $10.0 \mathrm{a}$ & $6.0 \mathrm{a}$ & $12.49 \mathrm{~b}$ \\
\hline 100 & $39.0 \mathrm{a}$ & $16.7 \mathrm{a}$ & $63.50 \mathrm{a}$ & $22.0 \mathrm{a}$ & $11.7 \mathrm{a}$ & $19.53 \mathrm{a}$ \\
\hline$\overline{\operatorname{LSD}(0.05)}$ & 13.57 & 11.41 & 24.22 & 12.69 & 9.74 & 5.721 \\
\hline CV $(\%)$ & 37.1 & 70.0 & 33.80 & 59.5 & 82.8 & 20.00 \\
\hline SE & 6.77 & 5.71 & 12.12 & 6.35 & 4.88 & 2.864 \\
\hline
\end{tabular}

$\mathrm{TSP}=$ Triple superphosphate, $\mathrm{TPR}=$ Togo phosphate rock,

Means bearing the same letter are not significantly different 
International Journal of Agriculture

ISSN 2520-4629X (Online)

Vol.6, Issue 1, No.2 pp 20 - 38, 2021

4.0 DISCUSSION, CONCLUSION AND RECOMMENDATION

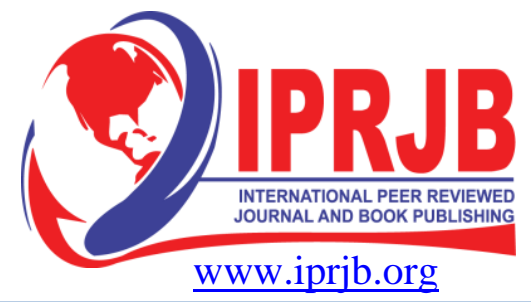

\section{Discussion}

\section{Physicochemical properties of Nzema and Adenta soil}

The Nzema series used in the study was more acidic than Adenta and the low $\mathrm{pH}$ of the Nzema soil may be attributed to the nature of the parent materials and partly to the intense leaching of bases caused by the high precipitation in the semi-deciduous zones. The high exchangeable acidity of the Nzema soil conforms to its low $\mathrm{pH}$ and moderate Al saturation. The low $\mathrm{pH}$ and moderate $\mathrm{Al}$ saturation of the Nzema soil may imply that there is a need for $\mathrm{P}$ application in order to improve crop growth on the soil because fairly high exchangeable $\mathrm{H}^{+}$ and Al cations in soil do significantly affect plant growth (Buol et al., 1973). The relatively higher organic carbon content of the Nzema soil was consistent with the observation that surface soils from the uncultivated forest soils have higher organic carbon content than those from the coastal savanna soil (Jones and Wild, 1957). The available P in the Adenta soil was found to be within the critical range suggested by Sahrawat et al (1997) while that of the Nzema soil was below the critical range.

\section{Effect of TSP and TPR application rates on nodulation of the legumes and N uptake}

The results from this study showed that with or without TSP or TPR soybean did not form nodules in the Nzema soil but nodulated with TSP application in the Adenta soil. The absence of nodulation even with high P from TSP is surprising but the observation in the Nzema soil may be attributed to the absence of soybean Rhizobium cells or insignificant numbers of these rhizobia. In the soil, Rhizobium species must recognize their specific host before nodulation may take place (Quispel, 1983) and the absence of the appropriate Rhizobium species with the introduction of a legume into a given soil may result in no or poor nodulation (Rupela et al., 1987).

Low $\mathrm{P}$ availability is a challenge for soybean crop species since the rhizobia responsible for nitrogen fixation have a high P requirement (Robson, 1983; Vance, 2001). The fact that no nodules were found in the control treatments in Nzema series of all the legume crops and TPR rates of soybean on Adenta soil, though TSP application showed nodulation, is enough proof that P plays a key role in nodule formation. According to Danso (1992), P is required by soybean for root development and $\mathrm{N}_{2}$ fixation. Adenta soil contains the soybean rhizobia (Bradyrhizobium japonicum) but as has been ascribed above, soybean rhizobia require high $\mathrm{P}$.

One factor that could have accounted for the better nodulation in Adenta soil compared to the Nzema soil is the higher acidity of the latter. The optimum $\mathrm{pH}$ for effective rhizobia growth in soils is between pH 6 and 7 (Jordan, 1984). Since the pH of the Nzema soil fell below the range, the poor nodulation and nodule dry weight can be linked to soil acidity (O'Hara et al., 1989; Graham, 1981; Dakora \& Philip, 2002). The bacteria symbionts might also have been directly affected by the soil acidity (Danso, 1977; Hungaria \& Vargas, 2000; Giller, 2001). Soil acidity may also affect early stages of infection process, which subsequently affected nodule formation (Hungaria \& Vargas, 2000; Giller, 2001).

Aluminum is also known to reduce meristematic activity if present in toxic concentrations (Robson, 1983) and this may also explain the reduction in nodule initiation and development 
The results of the present data indicated that treatments with higher $\mathrm{P}$ application gave higher $\mathrm{P}$ uptake and higher $\mathrm{N}$ uptake and showed the link among $\mathrm{P}$ application, dry matter, $\mathrm{P}$ uptake and $\mathrm{N}$ uptake. Phosphorus application to cowpea has been shown to improve the $\mathrm{N}$ contribution to subsequent maize (Abaidoo, et al 2007) and this has been demonstrated in this study. Nitrogen accumulated more than doubled when P was applied, especially with TSP application. Togo PR application also produced some significant effect in the $\mathrm{N}$ accumulation, especially at the rate of $100 \mathrm{mg} \mathrm{P} \mathrm{Kg}^{-1}$ almost on all the soil types by all the legumes but was not as effective as TSP. This suggests the greater effects of $\mathrm{P}$ on growth and activity of individual nodules rather than their numbers.

Differences in dry weight of nodules at different rates of $\mathrm{P}$ affirms the crucial role of $\mathrm{P}$ in nodule formation and the dry matter weight of nodules. It is clearly seen that TSP applications gave higher dry weight of nodules in the two soil series than the TPR and the positive correlation between $\mathrm{P}$ increment and the dry weight of nodules.

The significant differences in dry matter (nodule dry weight) and $\mathrm{N}$ accumulation among all the legumes used and this is in conformity with the work done by Oikeh et al (2008) who observed direct link between dry matter (nodule dry weight) and $\mathrm{N}$ accumulation in legumes.

\section{Conclusion}

Nodulation was heavily influenced by $\mathrm{P}$ availability and the presence or absence of a particular Rhizobia. This is supported by the fact that nodule number and nodule dry weight did better in the Adenta soil than the Nzema and therefore confirming the general belief that initial available $\mathrm{P}$ in a soil affects nodulation. Soybean did not nodulate in the Nzema soil and this stems from the fact that soybean rhizobia were not present in the soil. Even if the rhizobia were present, low $\mathrm{pH}, \mathrm{Al}$ toxicity and / or low $\mathrm{P}$ availability might have accounted for their inability to nodulate.

\section{Recommendation}

1. Research should be carried out to find out why there was no nodulation of soya bean in the Nzema soil at both TSP and TPR rates though pigeon pea and cow pea nodulated in the same soil. This is because pigeon pea rhizobia can nodulate cowpea and soybean and soybean rhizobia can also nodulate pigeon pea.

2. Again, more research is needed to ascertain why there was not any nodulation of soya bean in the Nzema Soil at both TSP and TPR rates yet there was exponential increment of the $\mathrm{N}$ uptake of fixed by the soya plant. 


\section{REFERENCES}

Abaidoo, R. C., Okogun, J. A., Kolawole G. O., Diels J., Randall P., Sanginga, N. (2007). Evaluation of cowpea genotypes for variations in their contribution of $\mathrm{N}$ and $\mathrm{P}$ to subsequent maize crop in three agro-ecological zones of West Africa. In Bationo, A; Waswa, B.; Kihara, J.; and Kimetu, J. (eds) Advances in integrated soil fertility management in sub Saharan Africa: challenges and opportunities. 1000pp

Abekoe, M. K \& Sahrawat, K. L. (2001). Phosphate retention and extractability in soils of the humid zone in West Africa. Geoderma, 102: 175-187

Acquaye, D. K. \& Oteng, J. W. (1972). Factor influencing the status of phosphorus on surfaces soils of Ghana. J. Agric. Science. 5: 221-228

Akinyele, I. O (1991). Effect of process method on the energy and protein content, antinutritional factors and in vitro protein digestibility of cowpea milk (Vigna unguiculata). Food Chem. 42: 129-134.

Bationo, A., Lompo, F., \& Koala, S., (1998) Research on nutrient flows and balances in West Africa: state-of-the-art. Agriculture, Ecosystems and Environment 71, 19-35

Boateng, A \& Owusu-Bennoah, E (2020). Assessment of Phosphorus availability from unreactive Togo Phosphate Rock by legume and cereal crops in two Ghanaian soil. International Peer Review Journal and Books: In Journal of Agriculture: Vol. 5, Issue 1. Pp 4-9.

Buol, S. W., Hole, F. D., \& McCracken, R. J. (1973). Soil Genesis and Classification, pp: 22.31. Iowa State Univ., Press, Iowa

Buresh, R. J., Smithson, P. \& Hellums, D. T. (1997). Building soil phosphorus capital in Africa. In R.J. Buresh, P.A. Sanchez \& F. Calhoun, eds. replenishing soil fertility in Africa, pp. 111-149. Madison, USA, SSSA Special Publication 51

CIAT (Centro internacional de Agricultura Tropical). (1992). Constraints to and opportunities for improving bean production. A planning document 1993-98. An achievement document 1987-92. Cali, Colombia; CIAT (Google scholar)

Dakora F. D. \& Philips D. (2002). Root exudates as mediators of mineral acquisition low nutrient soils. Plant Soil, 245: 35-47.

Danso, S. K. A (1992) Biological Nitrogen Fixation in Tropical Agrosystems: Twenty years of Biological Nitrogen Fixation research in Africa. In biological nitrogen fixation and sustainability of Tropical Agric. Pp 3-13. A Wiley-Sayce CoPublishing.

Danso, S. K. A. (1977). The ecology of Rhizobium and recent advances in the study of ecology of Rhizobium, In: Ayanaba A. and Dart P. J. (EDS). Biological nitrogen fixation in farming systems of the Humid Tropics. Pp 115-125. John Wiley and Sons. Chichester.

Giller, K. E. (2001) Nitrogen fixation in tropical cropping system, $2^{\text {nd }}$ edition. CABI International, Willingford, U.K. Pp 88, 254-257. 
Graham, P. H. \& Rosas J. C. (1981). Some problems of nodulation and symbiotic nitrogen fixation in Phaseolus vulgaris L. : A Review. Field crops Research, 4:93-112

Hungaria, M. \& Vargas, M. A. T. (2000) Environmental factors affecting $\mathrm{N}_{2}$-fixation in grain Legumes in the tropics with emphasis on Brazil. Field Crops Research. 65: 151-164. International Fertilizer Development Center (IFDC), (1984). Circular IFDC -S-8. (Annual Report). IFDC Muscle Shoals, Alabama

Israel D. W (1987). Investigation of the role of phosphorus in symbiotic dinitrogen fixation. Plant Physiology 84:835-840.

Jakobsen I. (1985). The role of phosphorus in nitrogen fixation by young pea plants (Pisum sativum) Physiologia Plantarum 64:190-196. Google scholar

Jones, M. J. \& Wild .A (1957) Soils of the West Africa Savanna. Commonwealth Agricultural Bureaux. Farnham Royal, Slough. First Edition. pp246

Jordan, D. C (1984). Rhizobiaceae. In: Krieg, N. K. and Hett, J. G. (eds). Bergey's Manual of Systematic Bacteriology, Vol. 1. Williams and Wilkins, Bathmore, Maryland, Pp 235-244.

Magadlela A, Perez-Fernadez M.A, Kleinert A, Dreyer L.L, Valentine A.J, (2016). Source of inorganic $\mathrm{N}$ affects the cost growth in a legume tree species (Virgilia divaricata) from Mediterranean-type fynbos ecosystem. Journal of Plant Ecology 9:752-761. (Google Scholar)

Magadlela A., Steenkamp E.T., Valentine A. J (2015). Variable P supply affect N metabolism in a legume tree, Virgilia divarcata, from nutrient-poor Mediterranean-type ecosystems. Functional Plant Biology 43:287-297.

Mokwunye, A. E. \& Vlek, P. L. G., eds. (1986). Management of nitrogen and phosphorus fertilizers in sub-Saharan Africa, pp. 173-224. Developments in Plant and Soil Sciences 24. Dordrecht, The Netherlands, Kluwer Academic Publishers

Mortimer P., Le Roux M.R., Perez-Fernadez M.A, Beneto V. A., Kleinert A, Xu J., Valentine A.J (2013). The dual symbiosis between arbuscular mycorrhiza and nitrogen fixing bacteria benefits the growth and nutrition of the woody invasive legume Acacia Cyclops under nutrient limiting. Plant and Soil 366:229-241

Nye, P. H. \& Bertheux, M. H. (1957). The distribution of phosphorus in forest and savanna soils of the Gold Coast and its agriculture significance. J. Agric. Science. 49: 141-159

O' Hara, G. W. Goss, T. J., Dilworth, M. J. \& Glenn, A. R (1989). Maintenance of intracellular $\mathrm{pH}$ and acid tolerance in Rhizobium meliloti. Applied and Environmental Microbiology, 55: 1870-1876

Oikeh, S. O., Houngnandan, P., Abaidoo, R. C., Rahimou, I., Toure, A., \& Niang, A., Akintayo, I (2008). Integrated soil fertility management involving promiscuous dual-purpose soybean and upland NERICA enhanced rice productivity in the savannas. Nutrient Cycling in Agroecosystems

Owusu-Bennoah, E. \& D. K. Acquaye, (1989). Phosphate sorption characteristics of selected major soils in Ghanaian soils. Soil Sci. 148: 1114-123. 
Owusu-Bennoah E. \& Szilas, C., Hansen, H. C. B. and Borggaard, O. K. (1997). Phosphorus sorption in relation to aluminium and iron oxides of Oxisols from Ghana. Commun. Soil. Sci. Plant Anal. 28: 685-697.

Pena \& J.Torrent. (1990). Predicting P sorption in soils of Mediterranean region Fert. Res.23:173-179

Perez-Fernadez M.A, Calvo-magro E, Rodriguez-Sanchez J, Valentive A (2017).differential growth costs and nitrogen fixation in Cytisus multiflorus (L'Her.) Sweet and Cytisus scoparius (L) link are mediated by sources of inorganic N. Plant Biology 19:742-748 (Google Scholar)

Quispel, A. (1983). Dinotrogen-fixing symbioses with legumes, non-legumes angiosperms and associative symbioses. In: Encyclopaedia of Plant Physiology, New Series (A, Lauchii and R. L. Bieleski, Eds.) Vol. 15a. Pp. 286-329. Spring Varlag, Berlin and New York.

Robson, A. D. (1983). Mineral nutrition. In WJ Broughton, ed, Nitrogen Fixation. Clarendon Press, Oxford, pp 36-55.

Rupela, O. P., Toomson, B., Mittal, S., Dart, P. J. \& Thompson, J. A. (1987). ChickpeaRhizobium populations: Survey of influence of season, soil depth and cropping pattern. Soil Biol. Biochem. 9:247-252.

Sahrawat, K. L., Jones, M. P. \& Diatta. S. (1997). Extractable phosphorus and rice yield in ultisol of the humid forest zone in West Africa. Commum. Soil Sci. Plant Anal. 28:711-716

Sample, E. C., Soper, R. J. \& Racz, G. J. (1980) Reactions of phosphate fertilizers in soils In: Khasawneh, F.E., Sample, E.C. and Kamprath, E.J. (eds) The role of Phosphorus in Agriculture, $1^{\text {st }}$ edn. ASA, CSSA, SSSA Madison, Wisconsin, pp. 263-310

Sanginga N., Okogun, J. K., Vanlauwe, B., Diels J., Carsky R. J., \& Dashiell, K. (2001). Nitrogen Contribution of Promiscuous Soybeans in Maize-based Cropping S Systems. SSSA Special Publication 58, Madison, USA, pp. 157-177.

Stevens G.G,. Perez-Fernadez M.A, Morcillo R.J.L., Kleinert A, Hills P., Brand D.J, Steenkamp, E.T., Valentine A.J (2019). Root and nodules response differently to $\mathrm{P}$ starvation in the Mediterranean-type legume Virgilia divaricate. Frontiers in Plant Science 10:73. Google scholar

Torrent. (1987). Rapid and slow Phosphate sorption by Mediterranean soils: Effect of iron oxides: Soil Sci. Soc. Am J.51:78-82

Vadez V, Lasso J.H, Beck D.P, Drevon, J.J (1999). Variability of N2-fixation in common beans (phaseolus vulgaris L.) under $\mathrm{P}$ deficiency is related to $\mathrm{P}$ use efficiency. Euphytic 106:231-242.

Vance, C. P. (2001) Symbiotic nitrogen fixation and phosphorus acquisition: plant nutrition in a world of declining renewable resources. Plant Physiol 127 390-397

Vanlauwe, B., Diels, J., Lyasse , O., Aihou, K., Iwuafor, E.N.O., Saginga, N., Merckx, R., \& Deckers, J., (2002).Fertility status of soils of derived savanna and northern guinea savanna and response to major plant nutrients, as influenced by soil 
International Journal of Agriculture

ISSN 2520-4629X (Online)

Vol.6, Issue 1, No.2 pp 20 - 38, 2021

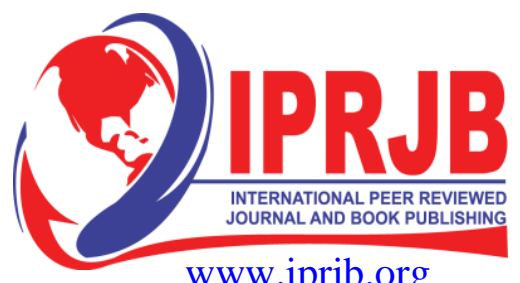

type and land use management. Nutrient Cycling in Agroecosystems 62, 139150

Vasileva, V., Kostov O (2002). Effect of water deficiency stress and N in yield of luceme (Medicago sativa L). Ecology and Future 1:104-107

Warren, G. P. (1992). Fertilizer phosphorus. Sorption and residual value in tropical African soils. NRI Bull. 37: 29-38 